\title{
Extracellular Vesicles as Potential Therapeutics for Inflammatory Diseases
}

\author{
Hee Sook Hwang ${ }^{1,2, \dagger}$, Hyosuk Kim ${ }^{1, \dagger}$, Geonhee Han ${ }^{1,3}$, Jong Won Lee ${ }^{1,3}$, Kwangmeyung Kim ${ }^{1,3}$, \\ Ick Chan Kwon ${ }^{1,3,4}$, Yoosoo Yang ${ }^{1, *}$ and Sun Hwa Kim ${ }^{1, *}$ \\ 1 Center for Theragnosis, Biomedical Research Institute, Korea Institute of Science and Technology (KIST), \\ Seoul 02792, Korea; hiya1092@gmail.com (H.S.H.); hyoseog7@kist.re.kr (H.K.); geonhee@kist.re.kr (G.H.); \\ j15387@kist.re.kr (J.W.L.); kim@kist.re.kr (K.K.); ikwon@kist.re.kr (I.C.K.) \\ 2 Department of Pharmaceutical Engineering, Dankook University, Cheonan 31116, Korea \\ 3 KU-KIST Graduate School of Converging Science and Technology, Korea University, Seoul 02841, Korea \\ 4 Department of Cancer Biology, Dana-Farber Cancer Institute, 450 Brookline Avenue, Boston, MA 02215, USA \\ * Correspondence: ysyang@kist.re.kr (Y.Y.); sunkim@kist.re.kr (S.H.K.) \\ + These authors contributed equally to this work.
}

\section{check for} updates

Citation: Hwang, H.S.; Kim, H.; Han, G.; Lee, J.W.; Kim, K.; Kwon, I.C.; Yang, Y.; Kim, S.H. Extracellular Vesicles as Potential Therapeutics for Inflammatory Diseases. Int. J. Mol. Sci. 2021, 22, 5487. https://doi.org/ 10.3390/ijms22115487

Academic Editors: Maria Pascual, Andreas Spittler,

Wolfgang Holnthoner and Viktoria Weber

Received: 4 May 2021

Accepted: 17 May 2021

Published: 22 May 2021

Publisher's Note: MDPI stays neutral with regard to jurisdictional claims in published maps and institutional affiliations.

Copyright: (c) 2021 by the authors. Licensee MDPI, Basel, Switzerland. This article is an open access article distributed under the terms and conditions of the Creative Commons Attribution (CC BY) license (https:// creativecommons.org/licenses/by/ $4.0 /)$.

\begin{abstract}
Extracellular vesicles (EV) deliver cargoes such as nucleic acids, proteins, and lipids between cells and serve as an intercellular communicator. As it is revealed that most of the functions associated to EVs are closely related to the immune response, the important role of EVs in inflammatory diseases is emerging. EVs can be functionalized through EV surface engineering and endow targeting moiety that allows for the target specificity for therapeutic applications in inflammatory diseases. Moreover, engineered EVs are considered as promising nanoparticles to develop personalized therapeutic carriers. In this review, we highlight the role of EVs in various inflammatory diseases, the application of EV as anti-inflammatory therapeutics, and the current state of the art in EV engineering techniques.
\end{abstract}

Keywords: extracellular vesicle; inflammatory disease; EV engineering; biomarker

\section{Introduction}

Extracellular vesicles (EVs), including exosomes and microvesicles, are secreted by almost all types of cells and carry genetic information between cells. Thus, EVs emerge as important contributor in cell-cell signaling and communication between cells. These EVs are characterized according to their size, with exosomes ranging from 50 to $100 \mathrm{~nm}$ and microveisicles usually larger than $200 \mathrm{~nm}$ [1,2]. EVs are able to transfer variety of cargos including proteins, lipids, antigen and RNAs such as miRNA, siRNA [2-4]. In addition, it has been reported that chromosomal DNA is present in certain types of EVs $[5,6]$. EVs have been reported to have a variety of functions and, in particular, contribute to antigen-specific and non-specific immune regulation to both immune and non-immune cells in the form of immunomodulation $[7,8]$. They also likely play an important role in modulating inflammatory diseases, such as cardiovascular disease, dermatitis, diabetes, and arthritis $[9,10]$.

With their given ability to modulate inflammation, EVs have tremendous potential as therapeutic agents and biomarkers. Since EVs have several advantages such as biocompatibility, low toxicity, low immunogenicity, and membrane permeability, they are considered as an ideal engineerable nanotherapeutic carrier for delivering various drugs and targeting inflammation. In this review, we focus on the role of EVs in various inflammatory diseases and their potential as therapeutic agents, and outline at the latest advances in EV engineering technologies for targeting and modulating inflammation. 


\section{The Role and Therapeutics Potential of Extracellular Vesicles in Inflammatory Diseases}

Recent research on the utility of EVs in inflammatory diseases is being studied in two broad fields. Currently, many researchers believe that EVs could be used as a potential biomarker for a liquid biopsy, an alternative to a typical biopsy characterized by various limitations, through studies of EV's role in inflammatory diseases [11-13]. On the other hand, it is suggested that EVs can also be utilized as therapeutic vehicles and targets for the treatment and prevention of inflammatory diseases. This section will focus on the role of EVs involved in the immune response, either directly or indirectly in inflammatory diseases, and discuss the therapeutic utility of various EVs (Table 1).

Table 1. Summary of therapeutic potential of extracellular vesicles according to disease.

\begin{tabular}{|c|c|c|c|c|c|}
\hline Disease & EV Source & $\begin{array}{l}\text { Effective } \\
\text { Molecule }\end{array}$ & Therapeutic Effect & Target Cell & References \\
\hline \multicolumn{6}{|l|}{$\begin{array}{l}\text { Cardiovascular } \\
\text { diseases }\end{array}$} \\
\hline $\begin{array}{l}\text { Cardiovascular } \\
\text { diseases }\end{array}$ & $\begin{array}{l}\text { Cardiosphere- } \\
\text { derived } \\
\text { cell }\end{array}$ & Y RNA fragment & $\begin{array}{l}\text { Increase the expression of } \\
\text { IL-10 }\end{array}$ & Cardiomyocyte & {$[14]$} \\
\hline $\begin{array}{c}\text { Cardiovascular } \\
\text { diseases }\end{array}$ & Dendritic cell & Not determined & Activate CD4+T cell & $\mathrm{CD} 4+\mathrm{T}$ cell & {$[15]$} \\
\hline $\begin{array}{l}\text { Cardiovascular } \\
\text { diseases }\end{array}$ & $\begin{array}{l}\text { Adipose-derived } \\
\text { stromal cells \& } \\
\text { mesenchymal stem } \\
\text { cell }\end{array}$ & $\begin{array}{l}\operatorname{miR}-93-5 p \& \\
\text { miR-181a }\end{array}$ & Suppress inflammation & $\begin{array}{l}\text { Hypoxic H9c2 cell \& } \\
\text { Peripheral blood } \\
\text { mononuclear cell }\end{array}$ & {$[16,17]$} \\
\hline $\begin{array}{l}\text { Cardiovascular } \\
\text { diseases }\end{array}$ & $\begin{array}{l}\text { Human umbilical } \\
\text { cord mesenchymal } \\
\text { stem cell }\end{array}$ & PA-GHRPS peptide & $\begin{array}{l}\text { Protect from oxidative } \\
\text { stress }\end{array}$ & H9C2 cell & [18] \\
\hline \multicolumn{6}{|l|}{ Skin inflammation } \\
\hline Cutaneous wound & $\begin{array}{l}\text { Human umbilical } \\
\text { cord blood }\end{array}$ & miR-21-3p & $\begin{array}{l}\text { Promote wound healing } \\
\text { factors }\end{array}$ & Human skin fibroblast & [19] \\
\hline Skin wound & Human keratinocyte & $\operatorname{miR}-21$ & $\begin{array}{c}\text { Mediate a } \\
\text { pro-inflammatory response }\end{array}$ & $\begin{array}{l}\text { Human foreskin } \\
\text { fibroblast }\end{array}$ & [20] \\
\hline $\begin{array}{l}\text { Chronic diabetic } \\
\text { wound }\end{array}$ & $\begin{array}{l}\text { Adipose-derived } \\
\text { mesenchymal stem } \\
\text { cell }\end{array}$ & Not determined & $\begin{array}{l}\text { Promoted proliferation and } \\
\text { angiogenesis }\end{array}$ & $\begin{array}{c}\text { Human umbilical vein } \\
\text { endothelial cell }\end{array}$ & {$[21]$} \\
\hline $\begin{array}{l}\text { Chronic diabetic } \\
\text { wound }\end{array}$ & $\begin{array}{l}\text { Human umbilical } \\
\text { cord blood } \\
\text { mononuclear cell }\end{array}$ & miR-150-5p & $\begin{array}{l}\text { Increase skin } \\
\text { neovascularization and } \\
\text { re-epithelization }\end{array}$ & $\begin{array}{l}\text { Human umbilical vein } \\
\text { endothelial cell \& normal } \\
\text { dermal human fibroblast }\end{array}$ & [22] \\
\hline \multicolumn{6}{|l|}{$\begin{array}{c}\text { Autoimmune } \\
\text { diseases }\end{array}$} \\
\hline RA & $\begin{array}{l}\text { IL-10-treated } \\
\text { dendritic cell }\end{array}$ & Not determined & Suppress inflammation & Not determined & {$[23]$} \\
\hline RA & $\begin{array}{c}\text { Mesenchymal stem } \\
\text { cell }\end{array}$ & Not determined & $\begin{array}{l}\text { Inhibit T lymphocyte } \\
\text { proliferation \& decrease the } \\
\text { percentage of CD4+ and } \\
\text { CD8+ T cell subsets }\end{array}$ & $\begin{array}{l}\text { T lymphocyte \& CD4+ } \\
\text { and CD } 8+\text { T cell }\end{array}$ & {$[24]$} \\
\hline $\begin{array}{c}\text { Autoimmune \& } \\
\text { Neurodegenerative } \\
\text { diseases }\end{array}$ & $\begin{array}{c}\text { IFN } \gamma \text {-treated } \\
\text { mesenchymal stem } \\
\text { cell }\end{array}$ & $\begin{array}{c}\text { IFN- } \gamma \& \\
\text { anti-inflammatory } \\
\text { RNAs }\end{array}$ & $\begin{array}{c}\text { Decrease pro-inflammatory } \\
\text { cytokines \& increase } \\
\text { immunosuppressive } \\
\text { cytokines }\end{array}$ & $\begin{array}{l}\text { CD4+CD25+FOXP3+ } \\
\text { regulatory T cells \& } \\
\text { peripheral blood } \\
\text { mononuclear cell }\end{array}$ & [25] \\
\hline EAE & $\begin{array}{l}\text { Gene-modified } \\
\text { dendritic cell }\end{array}$ & TGF- $\beta 1$ & $\begin{array}{c}\text { Decrease the frequency of } \\
\text { Th17 cell \& inhibit } \\
\text { proteolipid protein }\end{array}$ & Th17 cell \& CD4+T cell & [26] \\
\hline MS & $\begin{array}{l}\text { Engineered a murine } \\
\text { microglia cell }\end{array}$ & $\mathrm{IL}-4$ & $\begin{array}{l}\text { Increase anti-inflammatory } \\
\text { factors }\end{array}$ & Macrophages \& microglia & {$[27]$} \\
\hline $\mathrm{T} 1 \mathrm{D}$ & $\begin{array}{l}\text { Human } \\
\text { urine-derived } \\
\text { stem cell }\end{array}$ & Not determined & $\begin{array}{l}\text { Protect target cell from } \\
\text { apoptosis }\end{array}$ & $\begin{array}{c}\text { Human podocyte cell \& } \\
\text { tubular epithelial } \\
\text { cell }\end{array}$ & [28]. \\
\hline $\mathrm{T} 1 \mathrm{D}$ & $\begin{array}{c}\text { Mesenchymal stem } \\
\text { cell }\end{array}$ & Not determined & $\begin{array}{c}\text { Inhibit activation of } \\
\text { antigen-presenting cell \& } \\
\text { suppress development of } \\
\text { Th1 and Th17 cell }\end{array}$ & Not determined & {$[29,30]$} \\
\hline
\end{tabular}


Table 1. Cont.

\begin{tabular}{|c|c|c|c|c|c|}
\hline Disease & EV Source & $\begin{array}{l}\text { Effective } \\
\text { Molecule }\end{array}$ & Therapeutic Effect & Target Cell & References \\
\hline \multicolumn{6}{|l|}{$\begin{array}{l}\text { Respiratory system } \\
\text { inflammation }\end{array}$} \\
\hline Lung injury & $\begin{array}{l}\text { Mesenchymal stem } \\
\text { cell }\end{array}$ & $\operatorname{miR}-21-5 p$ & $\begin{array}{l}\text { Inhibits ROS-induced } \\
\text { apoptotic pathway }\end{array}$ & Epithelial cell & [31] \\
\hline Bacterial pneumonia & $\begin{array}{l}\text { Mesenchymal stem } \\
\text { cell }\end{array}$ & Not determined & $\begin{array}{c}\text { Increase the phagocytotic } \\
\text { activity }\end{array}$ & Neutrophil \& monocyte & [32] \\
\hline Lung injury & $\begin{array}{l}\text { Mesenchymal stem } \\
\text { cell }\end{array}$ & Not determined & $\begin{array}{c}\text { Polarize into M2 } \\
\text { macrophages }\end{array}$ & Alveolar macrophage & [33] \\
\hline Lung injury & $\begin{array}{l}\text { Mesenchymal stem } \\
\text { cell }\end{array}$ & Not determined & $\begin{array}{l}\text { Reducing the } \\
\text { pro-inflammatory cytokines }\end{array}$ & Regulatory $\mathrm{T}$ cell & [34] \\
\hline Lung fibrosis & $\begin{array}{l}\text { Mesenchymal stem } \\
\text { cell }\end{array}$ & Not determined & Suppress the maturation & Dendritic cell & [35] \\
\hline \multicolumn{6}{|l|}{ Neuroinflammation } \\
\hline Ischemic stroke & $\begin{array}{l}\text { Mesenchymal stem } \\
\text { cell }\end{array}$ & Not determined & Decrease the cell infiltration & Astrocyte \& leukocyte & [36] \\
\hline Alzheimer's disease & $\begin{array}{l}\text { Bone marrow stem } \\
\text { cell }\end{array}$ & BACE1 siRNA & $\begin{array}{l}\text { Reduce the expression of } \\
\text { disease-related proteins }\end{array}$ & Neuro2A cell & [37] \\
\hline Brain inflammation & Embryonic stem cell & Curcumin & $\begin{array}{l}\text { Reduce inflammation and } \\
\text { N-methyl-d-aspartate } \\
\text { receptor expression }\end{array}$ & Not determined & [38] \\
\hline Brain inflammation & EL-4 cell & Curcumin & $\begin{array}{l}\text { Decrease the percentage of } \\
\text { CD45.2+IL-1 } \beta+\text { cell }\end{array}$ & Not determined & [39] \\
\hline Neuroinflammation & Dendritic cell & miR-124 & $\begin{array}{l}\text { Alleviate cocaine-mediated } \\
\text { microglial activation }\end{array}$ & Microglia & [40] \\
\hline
\end{tabular}

\subsection{Cardiovascular Diseases}

2.1.1. Role of Extracellular Vesicles in Cardiovascular Diseases

Cardiovascular diseases (CVDs) are caused primarily by atherosclerosis, a chronic inflammatory disease in which the vascular endothelium is constantly damaged, causing endothelial dysfunction [41,42]. EVs of various cells such as leukocytes, platelets, smooth muscle cells and endothelial cells are involved in all stages of vascular inflammation, including endothelial activation, monocyte adhesion and transmigration, resulting in atherosclerosis $[9,43,44]$. Indeed, it has been reported that EVs can induce the release of pro-inflammatory cytokines, such as interleukin (IL)-6 and IL-8, from endothelial cells or leukocytes $[45,46]$. In addition, there have been reports that platelet-derived EVs enhance leukocyte adhesion by delivering pro-inflammatory molecules such as caspase-3 and RANTES protein to endothelial cells $[47,48]$. In view of these findings, it has been shown that circulating EV levels are associated with the occurrence of major cardiac dysfunction. Research on EVs as a prognostic and diagnostic biomarker is being actively conducted by improved EV purification technology and accurate content quantitative analysis technology.

\subsubsection{Therapeutic Potential of Extracellular Vesicles for Cardiovascular Diseases}

Inflammatory responses in CVDs have become a target for cardioprotection. After myocardial infarction (MI), immune cells infiltrate the infarcted area to remove the wounded tissue and participate in cardiac repair $[43,44]$. EVs affect cardiac repair by interacting with these invasive immune cells and modulating the polarization of immune cells and their secretion of cytokines. For example, cardiosphere-derived cell (CDC)-derived EVs loaded with Y-RNA fragments improved cardiac repair by increasing the release of IL-10 in the infarcted myocardium [14]. In addition, dendritic cell-derived EVs reduced the expression of pro-inflammatory cytokines by activating CD4-positive T cells [15]. Furthermore, several studies have been conducted to utilize EVs as drug delivery vehicles by overexpressing miRs, such as miR-93 and miR-181, which are related to cardiac repair, through genetic modification of the parental cells of EVs $[16,17]$. There have also been attempts to encapsulate EVs with functional peptide hydrogels in order to prolong EVs retention in the heart more than free EVs [18]. Despite the promising perspective on CVD treatment, EV-based 
therapies still need further investigation from experimental data to clinical application. Through a clear understanding of the mechanisms of EVs and controlling the balance between the harmful and beneficial effects of EVs in the heart, EVs could be utilized as new therapeutic tools to combat CVDs.

\subsection{Skin Inflammation}

\subsubsection{Role of Extracellular Vesicles in Inflammatory Skin Disorders}

Psoriasis, atopic dermatitis (AD), systemic lupus erythematosus (SLE), and chronic wound healing are refractory chronic inflammatory skin diseases. Inflammatory skin disorders that proceed through complex pathophysiological processes are also affected by EVs derived from various cells. First, psoriasis is the most common chronic inflammatory skin disease caused by abnormal differentiation and growth of keratinocytes and a large number of infiltrated immune cells [49]. Many studies have shown that endothelial and plateletderived EVs are elevated in patients with psoriasis [50-52]. Recently, potential biomarkers of psoriasis are being discovered through miRNA profiling analysis of plasma-derived EVs $[53,54]$. AD, one of the eczemas, is another common chronic inflammatory skin disease. Due to the findings that $\mathrm{AD}$ patients, characterized by dysfunction of the skin barrier, are susceptible to Staphylococcus aureus, several studies have explored the correlation between Staphylococcus aureus-derived EVs and AD. For example, it has been reported that Staphylococcus aureus-derived EVs increase the production of pro-inflammatory cytokines in dermal fibroblasts, activate endothelial cells, and induce monocyte recruitment $[55,56]$. In addition, EVs derived from thymol-treated Staphylococcus aureus showed their therapeutic potential for $\mathrm{AD}$ by alleviating skin lesions in $\mathrm{AD}$ [57]. SLE is a chronic inflammatory disease caused by the production of various autoantibodies due to viral infection, hormonal abnormalities etc. It harms multiple organs, and skin is the second most commonly affected organ [58]. According to an earlier reported study, the levels of EVs derived from annexin V non-binding cells were high in SLE patients, and the levels of IgG, IgM, and $\mathrm{C} 1 \mathrm{q}$ in EVs were elevated $[59,60]$. A recent study reported that distinct subpopulations of EVs may have different functions, and that there is an increase in mitochondrial-carrying IgG-positive large EVs in SLE patients [61]. Wound healing usually occurs in four stages: hemostasis, inflammation, proliferation and maturation. Chronic wound healing, which is common among diabetics and older people, is mostly stuck in the inflammatory phase and delayed wound healing. Numerous studies on EVs derived from various types of cells involved in the wound healing process have been reported [62-64]. Studies have shown that the expression level of miR-21 in EVs derived from keratinocytes in a mouse diabetes model is remarkably low [65]. In addition, there have been studies showing that advanced glycation end products induce human umbilical endothelial cells to secrete miR-106b-rich EVs, thereby reducing collagen synthesis and delaying skin wound healing [66].

\subsubsection{Therapeutic Potential of Extracellular Vesicles for Inflammatory Skin Disorders}

In dermatology research, EVs are starting to show promising prospects as a therapeutic for inflammatory skin diseases. Several studies have shown that EVs can be used as a therapeutic agent for wound healing. Umbilical cord blood-derived EVs rich in miR-21 accelerated cutaneous wound healing by promoting angiogenesis of endothelial cells and enhancing the migration and proliferation of fibroblasts [67]. Keratinocyte-derived EVs also facilitated wound healing by promoting angiogenesis and regulating fibroblast function through miR-21 [20]. Recently, a new approach to chronic inflammation treatment by combining these therapeutic EVs and biomaterials is being studied. A study has been reported to promote skin regeneration and accelerate wound healing through injectable antibacterial hydrogels with EVs derived from mesenchymal stem cells (MSCs) [21]. In addition, a study also reported that mononuclear cell-derived EVs carrying various miRs with a light-activatable hydrogel could promote wound healing [22]. EVs, especially exosomes, can also be used as drug delivery vehicles for inflammatory skin diseases. Choi et al. incorporated srIkB (super-repressor IkB) protein into exosomes by optogenetic 
method to inhibit the action of nuclear factor kappa-light-chain-enhancer of activated B cells (NF-kB), which plays a major role in activating inflammation [68]. However, these drug loading and targeting techniques must be applied in appropriate situations to suit their respective advantages, and standardization and deep understanding of techniques are also required to apply them to clinical trial.

\subsection{Autoimmune Diseases}

\subsubsection{Role of Extracellular Vesicles in Autoimmune Diseases}

Autoimmune disease refers to diseases such as rheumatoid arthritis (RA), multiple sclerosis (MS), and type 1 diabetes (T1D) caused by the self-immune system responding to autoantigen. There are many reports that the level of circulating EV increases in an autoimmune condition [69,70]. RA is a chronic inflammatory disorder that primarily affects joints. The pathogenesis of RA may be related to EVs involved in many complex cell-to-cell communications such as antigen presentation and inflammation $[69,71]$. It is known that synovial cell-derived EVs activate surrounding cells to secrete pro-inflammatory mediators for damaging cartilage [72]. MS, also known as encephalomyelitis, is an inflammatory demyelinating disease in which the insulating covering of nerve cells in the central nervous system is damaged by autoimmune activated immune cells [73,74]. It has been reported that EVs can transfer brain antigens to periphery through the blood brain barrier (BBB) [75]. T1D, formerly referred to as juvenile diabetes, is a form of diabetes in which little or no insulin is produced because autoimmunity destroys $\beta$ cells of the islet of Langerhans in the pancreas. Recent studies reported that EVs deliver autoantigen peptides involved in the pathogenesis of T1D to insulin-producing $\beta$ cells. A recent study reported that EVs deliver autoantigen peptides involved in the pathogenesis of T1D to insulin-producing $\beta$ cells, inducing apoptosis and resulting in insulin secretion disorders.

\subsubsection{Therapeutic Potential of Extracellular Vesicles for Autoimmune Diseases}

Receptors for pro-inflammatory cytokines such as TNF- $\alpha$ have also been reported to be found on the EV surface [76]. These findings suggest that EVs may act as an endogenous mechanism for receptor transfer to poorly expressed recipient cells or for the inhibition of inflammation by the release of decoy receptors. Thus, despite the major pathogenic role of EVs in autoimmune diseases, many researchers are currently attempting to utilize these bioparticles for therapeutic agents. Kim et al. reported that IL-10-treated dendritic cell-derived EVs can suppress the onset of arthritis and reduce the severity of established arthritis [23]. In addition, MSC-derived microparticles and exosomes both play an immunosuppressive role in inflammatory arthritis, but exosomes were more effective [24]. Based on the role of EVs in MS, several groups have developed therapeutic strategies that use the function of EVs. MSC-derived EVs stimulated with IFN- $\gamma$ carried anti-inflammatory factors and neuroprotective proteins and showed a good therapeutic effect on MS [25]. EVs derived from dendritic cells overexpressing TGF- $\beta 1$ have been shown to reduce the expression of MS by inhibiting Th1 and Th17 differentiation and promoting Treg production [26]. In addition, there has been a study to engineer a mouse microglial cell line to secrete exosomes that carry the anti-inflammatory cytokine IL-4 and overexpress the "eat me" signal MFG-E8 on its surface [27]. Zhuang also reduced neuroinflammation by loading curcumin or a signal transducer and activator of transcription 3 (Stat3) inhibitor into EVs and delivering them to microglia cells through a non-invasive intranasal route [39]. In treating T1D, EVs also have shown therapeutic potential. A study reported that EVs isolated from urine-derived stem cells can prevent kidney injury from diabetes by inhibiting apoptosis of podocytes and promoting angiogenesis [28]. Also, Lee et al. showed that MSC-derived EVs inhibit the activity of antigen-presenting cells and suppress the development of T helper cells, thereby reducing the immune response in T1D and uveitis animal models [29,30]. Collectively, with an understanding of the underlying mechanisms and roles of EVs associated with each stage of the disease, EVs can be used as a potential therapeutic tool for autoimmune diseases. 


\subsection{Respiratory System Inflammation}

\subsubsection{Role of Extracellular Vesicles in Respiratory System Inflammation}

Pulmonary inflammatory diseases can be categorized as either acute or chronic. Acute inflammation entails vasodilation and recruitment of immune-modulating cells at the site of the injury, while chronic inflammation is commonly characterized by fibrosis, a scarring of the lung tissue from a persistent inflammation [77,78]. In an acute inflammatory setting, like that of acute lung injury (ALI) and its more severe form (ARDS), inflammation causes a profound immune response throughout the body and the increased level of proinflammatory cytokines [79]. The role of EVs in reinforcing the process of inflammation has been extensively studied both in vitro and in vivo. Secreted EVs enable intercellular communication between damaged cells of lung tissue and alveolar macrophages or between alveolar macrophages [80,81]. Analysis of EVs from a bronchoalveolar fluid (BALF) expressed a high level of inflammatory molecules, both major histocompatibility complex (MHC) [82] and various miRNAs [83,84]. The contents and the main cellular source of BALF-EVs, however, varied based on the conditions and the type of stimulus. Depending on the mode of induction, the sterile method (toxicant, acid, or hypoxia) induced BALF-EVs and those induced by the non-sterile method (LPS or bacterial infection) vary in the major secreting cells as well as the interleukin profile within the BALF-EVs [85]. Each stimulus can induce micro-vesicles with different contents, and therefore, activates different pathways in receiving cells [81]. BALF-EVs from controlled asthmatic patients showed different miRNAs profiles control healthy subjects $[83,86]$. Exhaled breath condensates EVs from COPD, asthma, healthy individuals showed different miRNA expression: some were downregulated specifically to asthmatic patients (miR-1248, miR1291, and let-7a), while some were down-regulated in both COPD and asthmatic group (miR-328 and miR-21) [87,88]. In such a way, miRNAs in the EVs can serve as diagnostic and prognostic biomarkers for lung inflammation. For instance, let-7c and miR-125b from EVs are found to be inversely related to ARDS severity [31]. Besides miRNA analysis, levels of circulating EV can serve as the prognostic biomarkers of pulmonary inflammatory disease [89]. Increased circulating EVs were affiliated with a lower risk of ARDS in critically ill patients, thus providing insights into health and disease progression. The cellular origin of the EVs can also serve as the biomarker for ALI/ARDS: ARDS is associated with increased leukocyte-derived EVs, while ALI is associated with increased alveolar EVs [90].

\subsubsection{Therapeutic Potential of Extracellular Vesicles in Respiratory System Inflammation}

Mesenchymal stem cell therapy is regarded as a promising treatment option for both chronic and acute lung diseases [91]. Its potential application in tissue repair and suppression of inflammation has gained great attention. Some pulmonary inflammatory diseases, like ARDS/ALI, still have no treatment options [33]. MSC therapy showed promising results for ARDS/ALI, which raised high excitement and led to the development of several MSCs treatment agents [92]. In recent findings, immunomodulating effects of MSCs were attributed to MSC-secreted EVs [32]. Having comparative immune suppressive effects to MSC [34], MSC-EVs have several advantages over MSC as a therapeutic agent. MSC-EVs have a higher safety profile and lower immunogenicity; MSC-EVs could also avoid several unwanted side effects of MSC, such as immune rejection, clogging pulmonary capillaries, and stem cell-induced tumor formation [90,93]. MSC-EVs modulate inflammation in multiple pathways [35]. MSC-EVs protect epithelial cells from reactive oxidative species (ROS) by delivering miRNA 21-5p, which inhibits ROS-induced apoptotic pathways [31]. Besides anti-apoptotic miRNA, MSC-EVs contain anti-microbial proteins against Gram-negative bacteria. MSC-EVs increase the phagocytotic activity of neutrophils and monocytes; hence, bacterial pneumonia was less severe for the MSC-EVs treated group [32]. During the inflammatory phase, MSC-EVs induce an increase in phagocytosis; however, in a setting of resolution, MSC-EVs induce the alveolar macrophage polarization to M2 macrophages, which are commonly associated with wound healing and anti-inflammatory cytokines [33]. Thus, levels of immunosuppressive cytokines, like IL-10 and TGF-beta, increased while 
pro-inflammatory cytokines, like IL-8, IL-1 beta, and TNF-alpha, decreased [34]. Due to the high concentration of anti-inflammatory cytokines, dendritic cell maturation is suppressed, and it leads to additive anti-inflammatory effects [35]. For adaptive immunity, MSC-EVs inhibit $\mathrm{B}$ cell proliferation and differentiation, and they promote the differentiation of $\mathrm{T}$ helper cells to regulatory $\mathrm{T}$ cells, which causes an increase of anti-inflammatory cytokines (TGF-beta, IL-10, and PEG 2 ) and a decrease of pro-inflammatory cytokines (IFN-gamma, TNF-a, and IL-1 beta) [34].

\subsection{Neuroinflammation}

\subsubsection{Role of Extracellular Vesicles in Neuroinflammation}

EVs have both beneficial and detrimental roles in neuroinflammation. EVs can facilitate neuroinflammation by spreading the inflammatory signals from damaged cells to neighboring naïve neural cells [94]. The resident phagocytic cells within the brain, microglial cells, are known to be the first to respond in terms of neuroinflammation [95]. Once activated, microglial cells multiply in numbers, and each releases a greater number of ATP-filled EVs, sending danger signals across the brain. Thus, nearby microglial cells and astrocytes are stimulated and produce secrete inflammatory signals which further disseminate the inflammation. Besides worsening the inflammation via proinflammatory contents, EVs play crucial roles in several neurodegenerative disease progression, and consequently, lead to more pronounced chronic neuroinflammation [96]. Neural diseases, such as Alzheimer's disease, Parkinson's disease, traumatic brain injury (TBI), and multiple sclerosis (MS), all involve neuroinflammation and loss of cognitive function as the results [97]. The role of EVs as carriers of pathogenic proteins applies to Alzheimer's disease (AD), Parkinson's disease (PD), Creutzfeldt-Jacob disease (CJD), and amyotrophic lateral sclerosis (ALS) [98-100]. In the case of $\mathrm{AD}$ and PD, the main destructive effects are induced by the spreading of the causative agents: $\alpha \beta$ peptide and phosphorylated tau for $\mathrm{AD}, \alpha$-Syn for PD; in the case of $\mathrm{AD}$, ab protein aggregates formed extracellularly occurs as the cells get rid of ab with EVs. Meanwhile, through EVs, prion protein $\left(\mathrm{PrP}^{\mathrm{c}}\right)$ is carried across the brain, leading to overall damage [101]. Besides causing the conformational change of protein, these EVs contained higher levels of mRNAs that are related to neural disorders (miRs-29b, 128a, 146a) [97]. The specific interplay between neurodegenerative disease and neuroinflammation needs to be further clarified, but the interdependent relationship between neuroinflammation and the progression of neurodegenerative disease is confirmed in many recent studies [102-104]. As EVs move across the blood-brain barrier (BBB), transport of inflammatory materials from the peripheral to the brain can induce neuroinflammation, and in reverse, inflammation from the periphery can be the cause of neuroinflammation as well. HIV and HCV, typified by chronic peripheral inflammation, are associated with a higher rate of neurological problems. Individuals who suffered systemic autoimmune disease, also, showed a higher rate of the neurological disorder compared to healthy individuals [105].

\subsubsection{Therapeutic Potential of Extracellular Vesicles in Neuroinflammation}

EVs derived from MSC demonstrated its neuroprotective effects in several preclinical models [106]. In the preterm brain injury model, MSC-EV therapy reduced the rate of a histological sign of neuroinflammation and improved the inflammation-induced neuronal degeneration [107]. In the ischemic stroke model of rats, intra-arterial injection of MSC-EV has been shown to decrease the cell activation of astrocytes, microglia, and infiltrating leukocytes [36]. MSC-EV therapy leads to suppression of pro-inflammatory cytokines, TNF$\alpha$ and IL- $1 b$, and reduced secretion of anti-inflammatory cytokines, IL-10 and TGF- $\beta$ [35]. Besides their neuroprotective effects, EVs have shown potential as drug delivery vehicles due to their safety and targetability based on their origin [108]. Especially in neural disease, crossing BBB remains a challenge for potential promising therapies. As intravenous EV injection has been found to cross BBB and target brain cells [37], MSC-EV can serve as the optimal carrier for various neuroinflammatory diseases. Curcumin-loaded EVs have 
demonstrated neuroprotective effects in the ischemia-reperfusion injury model and LPS induced brain inflammation [38]. In the setting of LPS induced brain inflammation model, EVs packaged with curcumin have been delivered intranasally and efficaciously induced selective curcumin-loaded EV uptake by activated resident immune cells and induced apoptosis in those pro-inflammatory neural cells [105]. Besides loading anti-inflammatory chemical compounds, MSC-EVs have been utilized extensively as the delivery vehicle for gene therapy to the brain [37]. Specifically, MSC-EV mediated transport of miR-124 is found to reduce the neuroinflammation: in cocaine mediated brain inflammation, intranasal delivery of miR-124 loaded EVs to the brain dampened the secretion of proinflammatory cytokines (TLR4, STAT3, NF-kB p65, and MYD88) and ceased the activation of microglia [40]. A clinical trial of MSC-EVs for brain inflammation is currently ongoing for acute ischemic stroke (NCT03384433). However, further pre-clinical and clinical studies need to be done to determine the full potential of MSC-EV usage in brain inflammation [106].

\section{Surface Engineering Techniques of EVs}

The surface modification of EVs is a necessary step for practical applications because surface engineering brings additional functionality to EVs and allow targeting, enhanced intracellular uptake, and prolonged circulation time. There are two main approaches that classify surface engineering (Scheme 1).

\subsection{Cell Engineering}

Cell engineering is a method that introduce peptides, proteins, and antibodies on the surface of EVs. The cell surface is engineered by fusing proteins of interest, introducing targeting peptides, or immobilizing proteins to the inner surface of EVs $[109,110]$.

Fusion of proteins with the Lactadherin $\mathrm{C} 1 \mathrm{C} 2$ domain has been found to bind exosome lipids [111]. In more detail, the $\mathrm{C} 1 \mathrm{C} 2$ domain of Lactadherin provides exosome targeting strategy, where fusion proteins to the $\mathrm{C} 1 \mathrm{C} 2$ domain of Lactadherin generates chimeric proteins that bind to exosome lipids. Thus, exosome enables the production of multiple copies of antigens bounding particles and provides immune system that can react to encounter foreign microorganisms. Hatman et al. also coupled carcinoembryonic antigen (CEA) and HER2 to the C1C2 domain of Lactadherin and found that the fusion proteins showed enhanced expression in exosomes and antigen specific immune responses for enhanced therapeutic anti-tumor effects [112].

Genetic engineering is able to introduce targeting peptides on the surface of EVs. The Lamp2b is a protein that found in exosomal membranes and one of the proteins that has been and widely applied with targeting peptides [37,113]. For example, targeting was achieved by fusing Lamp2b to the neuron specific rabies viral glycoprotein (RVG) peptide [37]. When the Lamp2b constructs were transfected to dendritic cells, Lamp2b was strongly expressed in dendritic cells and the constructs successfully endowed exosomes with cell targeting ability. In addition, Lamp2b was fused to $\alpha v$ integrin-specific iRGD peptide to facilitate tumor targeting ability by engineering immature mouse dendritic cell line (imDC) [114]. The engineering of imDCs expressed Lamp2b and the iRGD exosomes from imDCs loaded with DOX showed highly efficient targeting and demonstrated enhanced DOX delivery to $\alpha v$ integrin-positive breast cancer cells.

Genetic engineering can be also applied to immobilize proteins to the inner surface of exosomes. For example, cryptochrome 2 (CRY2)-conjugated cargo proteins to the exosomes were designed by encoding CIBN to an exosome-associated tetraspanin protein CD9 with blue light illumination [115]. When the cargo proteins are introduced into the exosomes via biogenesis, it is detached from CD9-conjugated CIBN by light illumination and release into the exosomal intraluminal space and efficiently deliver to target cells. Thus, protein-loaded exosomes demonstrated enhanced intracellular levels of cargo proteins and their function in recipient cells. Shalitin et al. also reported that CRY2 undergoes a blue-light-dependent phosphorylation and proposed that the absorption of photons by a 
cryptochrome undergoes its conformation change and triggers signal transduction and physiological responses [116].

\section{Surface engineering}

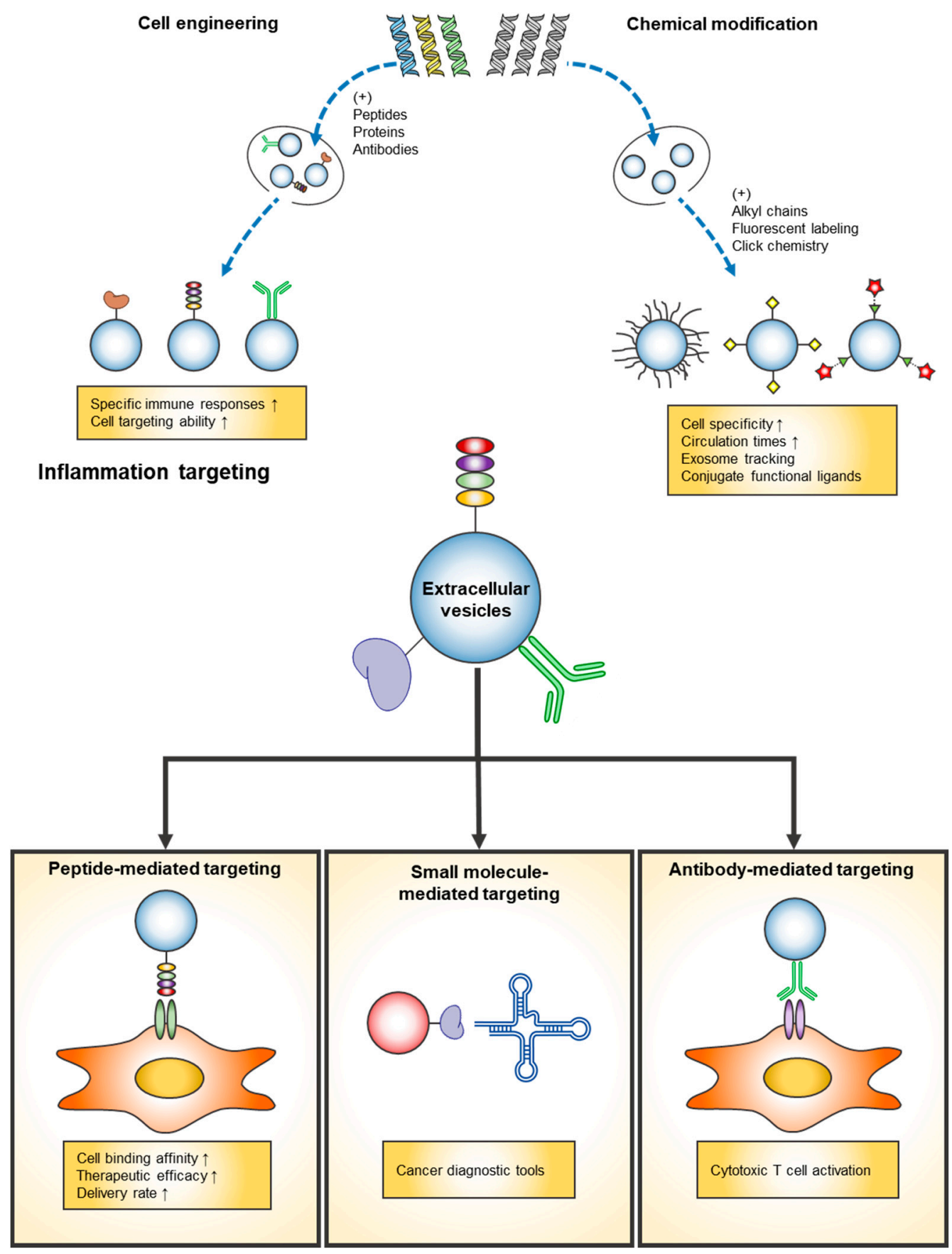

Scheme 1. Surface engineering techniques of EVs and targeting strategies for inflammation. Cell engineering methods that express peptides, proteins and antibodies on the EV surface could enhance specific immune responses and cell targeting capabilities. The method of attaching various substances through chemical modification could provide new functions different from normal EV. These EVs could achieve increased cell specificity and circulation times. In addition, it can be applied to inflammation by activating immune cells with peptides or antibodies expressed on the EVs surface, and by diagnosing cancer proteins on the EVs surface using aptamers. Attachment of specific peptides to EVs increases cell binding affinity, therapeutic efficacy, and delivery rate, and attachment of specific antibodies can lead to activation of cytotoxic T cells. 


\subsection{Chemical Modification}

One way to anchor molecules into the lipid bilayer of exosomes are using alkyl chains through hydrophobic interactions. Koojimans et al. decorated EVs with targeting ligands conjugated to polyethylene glycol (PEG). The introduction of PEG-conjugated nanobodies to EVs provided cell specificity and prolonged circulation times while unmodified EVs rapidly cleared from the circulation in in vivo studies [117]. In addition, exosomes were labelled using the PKH26 Red Fluorescent [118]. When exosomes derived from mammary epithelial cells labelled with PKH26 were incubated with tumor cells, the exosomes were efficiently incorporated into the tumor cells. Exosomes isolated from bladder cancer were labelled with PKH26 and showed that exosome uptake based on the number of PKH26 positive spots is dose and time dependent [119]. Smyth et al. also demonstrated DIR incorporated into exosomes, where DIR is fluorescent that label exosomes [120]. They labelled exosomes with the lipophilic fluorescent tracer DIR and used them to study exosomes' rates of clearance and biodistribution. These studies were performed to stain exosomal membranes by the intercalation of aliphatic chains into lipid bilayers.

In addition, there are another method for conjugation of ligands to the exosome surface via click chemistry. Click chemistry, also called Copper-catalyzed azide alkyne cycloaddition, is a highly efficient reaction that forms a thiazole linkage between an alkyne and an azide group [121]. Thus, the alkynes are first grafted to the EV membrane and then react with azide group of molecules of interest and form azide-alkyne cycloaddition. Presolski et al. also used the click chemistry for the coupling of cargo-azide to biomoleculealkyne and designed azaide-modified fluorophores [122]. Click chemistry was also used to conjugate functional ligands onto exosomal surfaces and Tian's group proposed the cyclo(Arg-Gly-Asp-D-Tyr-Lys) peptide that shows high affinity to integrin $\alpha \mathrm{v} \beta 3$ was conjugated on mesenchymal stromal cell (MSC)-derived exosomes [123].

\section{Strategies for Inflammation Targeting EVs}

EVs have been decorated with various targeting ligands including peptides, small molecules, antibodies, and aptamers to obtain active targeting. EVs are modified to target inflammatory cells for anti-inflammation therapy.

\subsection{Peptide-Mediated Targeting}

The cyclo(Arg-Gly-Asp-D-Tyr-Lys) peptide has been conjugated on the surface of exosome via bio-orthogonal chemistry to target the lesion region of the ischemic brain [123]. The MSC-derived exosomes conjugated with peptide showed high affinity to integrin $\alpha v \beta 3$ in reactive cerebral vascular endothelial cells. Wang et al. designed exosomal enriched membrane protein (Lamp2b) fused to ischemic myocardium-targeting peptide CSTSMLKAC (IMTP) and found MSC-derived IMTP-exosome exhibited enhanced therapeutic efficacy on acute myocardial infarction [67]. In addition, exosome expressing cardiac-targeting peptide (CTP)-Lamp2b were generated by Kim's group and CTP-exosome showed 15\% enhanced delivery of exosomes to the heart cell and heart tissue of mice [124]. Zhang et al. used cyclo $(1,12)$ PenITDGEATDSGC (cLABL) peptide that is known to bind and upregulate intercellular cell-adhesion molecule-1 (ICAM-1) on HUVEC [125]. They demonstrated the inflammation-targeting peptide is inducing inhibition of the infiltration of immune cells via blockage or internalization of ICAM-1 receptors on HUVEC. Vascular cell adhesion molecule-1 (VCAM-1) peptide was also proposed as an inflammation-targeting peptide to identify the inflammatory activation of cells involved in atherosclerosis [126].

\subsection{Small Molecule-Mediated Targeting}

Small molecule targeting ligands are referred to targeted delivery that have an average molecular weight less than $1 \mathrm{kDa}$. The small molecule-based targeting strategy has been applied in EV-based therapies. Pi et al. developed siRNA-loaded nanoparticles and displayed folate on the outer surface of the EVs [127]. Folate is known as an attractive targeting ligand since many cancers overexpress folate receptors [128]. They demonstrated 
that folate displayed EVs inhibited colorectal cancer growth in mice. In addition, monosaccharides such as glucose and galactose are another class of small molecule targeting ligands. Glucose targets the GLUT1 receptor that is overexpressed at the blood-brain barrier and its derivative modified therapeutic modalities have been studied for glioma targeting [129].

As a low molecular weight targeting system, aptamer was also used in several studies for aptamer-mediated inflammation targeting strategy. Aptamers also known as chemical antibodies can function as therapeutic and diagnostic tools due to its target-binding, no immunogenicity, and deep tumor penetration [130]. Aptamer-guided exosome capturing nanoplatform system has been developed as a diagnostic tool. For example, aptamer was utilized to capture HSP70 positive exosomes in urine samples taken from breast, ovarian, or lung cancer patients [131]. Li et al. designed an exosome that targets dendritic cells (DC-Exosome). MSCs derived exosomes was applied to the mTOR siRNA delivery system of targeting dendritic cells. Aptamer/siRNA chimera performed the targeted delivery of microRNAs into DCs and maintained long-term immune tolerance [132].

\subsection{Antibody-Mediated Targeting}

Antibodies for immune cells or tissue cells are also introduced on the surface of EVs, which allows specific inflammation targeting. Exosomes can be act as artificial cellular immunity controller to activate cytotoxic $\mathrm{T}$ cells for cancer cell killing by modification via antibody fusion [133]. Exosome fused with antibody was called synthetic multivalent antibodies retargeted exosomes (SMART-Exos) and provided a versatile platform technology for immunotherapy as well as a potent anticancer immune response.

\section{Challenges and Perspectives}

EVs have great interest and importance in therapeutic applications for the clinic due to biocompatibility as a nature nanoplatform. They have exhibited therapeutic potential in various inflammatory diseases including autoimmune diseases, neurology diseases, and myocardial diseases. To date, several phase I or phase II clinical trials have been conducted based on considerable evidence of their therapeutic utility accumulated in preclinical studies (Table 2). However, the practical therapeutic application of EVs faces significant challenges. The major challenges that must be addressed before turning EVs to the clinic are: (i) large-scale production, (ii) content analysis of EVs and (iii) EVs engineering technology control. The separation of EVs from cell culture media is carried out by methods such as laboratory scale ultracentrifugation or filtration. The yield of EV obtained from these methods may vary slightly depending on the type of cultured cells, but is generally very poor. Therefore, standard EVs production methods need to be developed for large scale production, rapid isolation, and quality control. Also, the analysis of EVs is focused on the content of the EVs. Cell-derived EVs represent the properties such as nature and function of the donor cells. However, until now, there has been only a little way to know how to represent the properties. Prior to the engineering of EVs, the content should be characterized in the contexts of EVs heterogeneity. In therapeutic applications of EVs, it may be necessary to discover and recognize the contents that cause therapeutic effects or side effects. Also, content analysis needs to be linked to standards for the evaluation of EVs. Through the overall content analysis and evaluation standard, the specific donor cells can be selected for the treatment of the specific diseases. In terms of engineering technology, therapeutic molecules, including chemical drugs, genetic material, and proteins, have been loaded on EVs. During the engineering process, the loading efficiency of cargo to be loaded onto EVs should be controllable and should not affect the inherent characteristics of EVs. Changes in the size and surface potential of EVs can affect the biological activity and therapeutic efficacy of EVs. 
Table 2. Human clinical trials of EVs in inflammatory diseases.

\begin{tabular}{|c|c|c|c|c|}
\hline Disease & Phase & Source of Exosomes & Results and Status & NCT Numbers \\
\hline $\begin{array}{l}\text { Cutaneous wound } \\
\text { healing }\end{array}$ & $\begin{array}{l}\text { Phase I } \\
(n=5)\end{array}$ & Plasma derived exosomes & Enrolling & NCT02565264 \\
\hline Skin graft & $\begin{array}{l}\text { Phase I } \\
(n=24)\end{array}$ & Platelet derived extracellular vesicles & Enrolling & NCT04664738 \\
\hline Diabetes Mellitus Type 1 & $\begin{array}{l}\text { Phase II, III } \\
\quad(n=20)\end{array}$ & $\begin{array}{l}\text { Umbilical cord blood derived mesenchymal } \\
\text { stem cell exosomes }\end{array}$ & Unknown & NCT02138331 \\
\hline $\begin{array}{l}\text { Severe Coronavirus } \\
\text { pneumonia, ARDS }\end{array}$ & $\begin{array}{l}\text { Phase II } \\
(n=60)\end{array}$ & Bone marrow derived extracellular vesicles & Not yet recruiting & NCT04493242 \\
\hline $\begin{array}{l}\text { Severe Coronavirus } \\
\text { pneumonia }\end{array}$ & $\begin{array}{l}\text { Phase I } \\
(n=24)\end{array}$ & $\begin{array}{c}\text { Allogenic adipose mesenchymal stem cell } \\
\text { derived exosome }\end{array}$ & Completed & NCT04276987 \\
\hline $\begin{array}{l}\text { Severe Coronavirus } \\
\text { pneumonia }\end{array}$ & $\begin{array}{l}\text { Phase II } \\
(n=90)\end{array}$ & Mesenchymal stem cell derived exosome & Enrolling & NCT04602442 \\
\hline $\begin{array}{l}\text { Acute respiratory distress } \\
\text { syndrome }\end{array}$ & $\begin{array}{l}\text { Phase I, II } \\
(n=169)\end{array}$ & $\begin{array}{c}\text { Allogenic human mesenchymal stem cell } \\
\text { derived exosomes }\end{array}$ & Not yet recruiting & NCT04602104 \\
\hline Acute Ischemic Stroke & $\begin{array}{l}\text { Phase I, II } \\
\quad(n=5)\end{array}$ & $\begin{array}{c}\text { Allogenic mesenchymal stem cell derived } \\
\text { exosome }\end{array}$ & Recruiting & NCT03384433 \\
\hline
\end{tabular}

The field of EVs therapeutics has been rapidly growing with advanced nanotechnology. As a natural nanoplatform, EVs provide a powerful option for overcoming the challenges of inflammatory diseases, including potential toxicity and complexity. EVs engineered with nanotechnology have shown enhanced therapeutic efficacy. Especially, recent studies for selective drug encapsulation were focused on the sorting machinery working in EVs biogenesis and release. Therefore, uncovering the biological pathway related to the packaging of EVs may provide us with the novel tools for improving EVs-based therapy. In addition, a light-triggered drug loading technique was developed by integrating optically light reversible protein interaction module and EVs biogenesis and release process. [115]. This research may suggest the importance of conversing technology with other research fields such as mechanics, electronics, optics, and omics. The future application of EVs in the detection and treatment of various inflammatory diseases will be possible through deep and broad collaboration between different fields.

Author Contributions: Conceptualization, comprehensive writing, reviewing, figure generation, and manuscript preparation, H.S.H., H.K., Y.Y., and S.H.K.; Writing and review, H.S.H., H.K., G.H., and J.W.L.; Writing, review, and figure generation, H.S.H., H.K., and G.H.; Funding acquisition K.K., I.C.K., Y.Y., and S.H.K.; All authors have read and agreed to the published version of the manuscript.

Funding: This study was supported by the Mid-career Researcher Program (NRF-2019R1A2C2010408), Brain Pool Program (NRF-2020H1D3A1A02081401) and Intramural Research Program of Korea Institute of Science and Technology (KIST).

Institutional Review Board Statement: Not applicable.

Informed Consent Statement: Not applicable.

Data Availability Statement: Not applicable.

Conflicts of Interest: The authors declare no conflict of interest.

\section{Abbreviations}

EVs Extracellular Vesicles

PEG Polyethylene Glycol

MSCs Mesenchymal Stem Cells

CVDs Cardiovascular Diseases 


$\begin{array}{ll}\text { IL } & \text { Interleukin } \\ \text { AD } & \text { Atopic Dermatitis } \\ \text { SLE } & \text { Systemic Lupus Erythematosus } \\ \text { RA } & \text { Rheumatoid Arthritis } \\ \text { MS } & \text { Multiple Sclerosis } \\ \text { T1D } & \text { Type 1 Diabetes } \\ \text { ALI } & \text { Acute Lung Injury } \\ \text { ARDS } & \text { Acute Respiratory Distress Syndrome } \\ \text { BALF } & \text { Bronchoalveolar Fluid } \\ \text { COPD } & \text { Chronic Obstructive Pulmonary Disease } \\ \text { ROS } & \text { Reactive Oxidative Species } \\ \text { AD } & \text { Alzheimer's Disease } \\ \text { PD } & \text { Parkinson's Disease }\end{array}$

\section{References}

1. Raposo, G.; Stoorvogel, W. Extracellular vesicles: Exosomes, microvesicles, and friends. J. Cell Biol. 2013, 200, 373-383. [CrossRef] [PubMed]

2. Andaloussi, S.E.L.; Mager, I.; Breakefield, X.O.; Wood, M.J. Extracellular vesicles: Biology and emerging therapeutic opportunities. Nat. Rev. Drug Discov. 2013, 12, 347-357. [CrossRef] [PubMed]

3. Agrahari, V.; Agrahari, V.; Burnouf, P.A.; Chew, C.H.; Burnouf, T. Extracellular Microvesicles as New Industrial Therapeutic Frontiers. Trends Biotechnol. 2019, 37, 707-729. [CrossRef] [PubMed]

4. Wiklander, O.P.B.; Brennan, M.A.; Lotvall, J.; Breakefield, X.O.; El Andaloussi, S. Advances in therapeutic applications of extracellular vesicles. Sci. Transl. Med. 2019, 11. [CrossRef] [PubMed]

5. Balaj, L.; Lessard, R.; Dai, L.; Cho, Y.J.; Pomeroy, S.L.; Breakefield, X.O.; Skog, J. Tumour microvesicles contain retrotransposon elements and amplified oncogene sequences. Nat. Commun. 2011, 2, 180. [CrossRef] [PubMed]

6. Robbins, P.D.; Morelli, A.E. Regulation of immune responses by extracellular vesicles. Nat. Rev. Immunol. 2014, 14, 195-208. [CrossRef] [PubMed]

7. Dorronsoro, A.; Fernandez-Rueda, J.; Fechter, K.; Ferrin, I.; Salcedo, J.M.; Jakobsson, E.; Trigueros, C. Human mesenchymal stromal cell-mediated immunoregulation: Mechanisms of action and clinical applications. Bone Marrow Res. 2013, 2013, 203643. [CrossRef] [PubMed]

8. Slomka, A.; Urban, S.K.; Lukacs-Kornek, V.; Zekanowska, E.; Kornek, M. Large Extracellular Vesicles: Have We Found the Holy Grail of Inflammation? Front. Immunol. 2018, 9, 2723. [CrossRef]

9. Lam, K.C.K.; Lam, M.K.N.; Chim, C.S.; Chan, G.C.F.; Li, J.C.B. The functional role of surface molecules on extracellular vesicles in cancer, autoimmune diseases, and coagulopathy. J. Leukoc. Biol. 2020, 108, 1565-1573. [CrossRef] [PubMed]

10. Turpin, D.; Truchetet, M.E.; Faustin, B.; Augusto, J.F.; Contin-Bordes, C.; Brisson, A.; Blanco, P.; Duffau, P. Role of extracellular vesicles in autoimmune diseases. Autoimmun. Rev. 2016, 15, 174-183. [CrossRef]

11. Li, W.; Wang, H.; Zhao, Z.; Gao, H.; Liu, C.; Zhu, L.; Wang, C.; Yang, Y. Emerging Nanotechnologies for Liquid Biopsy: The Detection of Circulating Tumor Cells and Extracellular Vesicles. Adv. Mater. 2019, 31, e1805344. [CrossRef] [PubMed]

12. Rappa, G.; Puglisi, C.; Santos, M.F.; Forte, S.; Memeo, L.; Lorico, A. Extracellular Vesicles from Thyroid Carcinoma: The New Frontier of Liquid Biopsy. Int. J. Mol. Sci. 2019, 20, 1114. [CrossRef] [PubMed]

13. Yoshioka, Y.; Kosaka, N.; Konishi, Y.; Ohta, H.; Okamoto, H.; Sonoda, H.; Nonaka, R.; Yamamoto, H.; Ishii, H.; Mori, M.; et al. Ultra-sensitive liquid biopsy of circulating extracellular vesicles using ExoScreen. Nat. Commun. 2014, 5, 3591. [CrossRef] [PubMed]

14. Cambier, L.; de Couto, G.; Ibrahim, A.; Echavez, A.K.; Valle, J.; Liu, W.; Kreke, M.; Smith, R.R.; Marban, L.; Marban, E. Y RNA fragment in extracellular vesicles confers cardioprotection via modulation of IL-10 expression and secretion. EMBO Mol. Med. 2017, 9, 337-352. [CrossRef]

15. Liu, H.; Gao, W.; Yuan, J.; Wu, C.; Yao, K.; Zhang, L.; Ma, L.; Zhu, J.; Zou, Y.; Ge, J. Exosomes derived from dendritic cells improve cardiac function via activation of CD4(+) T lymphocytes after myocardial infarction. J. Mol. Cell. Cardiol. 2016, 91, 123-133. [CrossRef] [PubMed]

16. Liu, J.; Jiang, M.; Deng, S.; Lu, J.; Huang, H.; Zhang, Y.; Gong, P.; Shen, X.; Ruan, H.; Jin, M.; et al. miR-93-5p-Containing Exosomes Treatment Attenuates Acute Myocardial Infarction-Induced Myocardial Damage. Mol. Ther. Nucleic Acids 2018, 11, $103-115$. [CrossRef] [PubMed]

17. Wei, Z.; Qiao, S.; Zhao, J.; Liu, Y.; Li, Q.; Wei, Z.; Dai, Q.; Kang, L.; Xu, B. miRNA-181a over-expression in mesenchymal stem cell-derived exosomes influenced inflammatory response after myocardial ischemia-reperfusion injury. Life Sci. 2019, $232,116632$. [CrossRef] [PubMed]

18. Han, C.; Zhou, J.; Liang, C.; Liu, B.; Pan, X.; Zhang, Y.; Wang, Y.; Yan, B.; Xie, W.; Liu, F.; et al. Human umbilical cord mesenchymal stem cell derived exosomes encapsulated in functional peptide hydrogels promote cardiac repair. Biomater. Sci. 2019, 7, 2920-2933. [CrossRef] [PubMed] 
19. Hu, Y.; Rao, S.S.; Wang, Z.X.; Cao, J.; Tan, Y.J.; Luo, J.; Li, H.M.; Zhang, W.S.; Chen, C.Y.; Xie, H. Exosomes from human umbilical cord blood accelerate cutaneous wound healing through miR-21-3p-mediated promotion of angiogenesis and fibroblast function. Theranostics 2018, 8, 169-184. [CrossRef]

20. Li, Q.; Zhao, H.; Chen, W.; Huang, P.; Bi, J. Human keratinocyte-derived microvesicle miRNA-21 promotes skin wound healing in diabetic rats through facilitating fibroblast function and angiogenesis. Int. J. Biochem. Cell Biol. 2019, 114, 105570. [CrossRef]

21. Wang, C.; Wang, M.; Xu, T.; Zhang, X.; Lin, C.; Gao, W.; Xu, H.; Lei, B.; Mao, C. Engineering Bioactive Self-Healing Antibacterial Exosomes Hydrogel for Promoting Chronic Diabetic Wound Healing and Complete Skin Regeneration. Theranostics 2019, 9, 65-76. [CrossRef] [PubMed]

22. Henriques-Antunes, H.; Cardoso, R.M.S.; Zonari, A.; Correia, J.; Leal, E.C.; Jimenez-Balsa, A.; Lino, M.M.; Barradas, A.; Kostic, I.; Gomes, C.; et al. The Kinetics of Small Extracellular Vesicle Delivery Impacts Skin Tissue Regeneration. ACS Nano 2019, 13, 8694-8707. [CrossRef] [PubMed]

23. Kim, S.H.; Lechman, E.R.; Bianco, N.; Menon, R.; Keravala, A.; Nash, J.; Mi, Z.; Watkins, S.C.; Gambotto, A.; Robbins, P.D. Exosomes derived from IL-10-treated dendritic cells can suppress inflammation and collagen-induced arthritis. J. Immunol. 2005, 174, 6440-6448. [CrossRef]

24. Cosenza, S.; Toupet, K.; Maumus, M.; Luz-Crawford, P.; Blanc-Brude, O.; Jorgensen, C.; Noel, D. Mesenchymal stem cells-derived exosomes are more immunosuppressive than microparticles in inflammatory arthritis. Theranostics 2018, 8, 1399-1410. [CrossRef] [PubMed]

25. Riazifar, M.; Mohammadi, M.R.; Pone, E.J.; Yeri, A.; Lasser, C.; Segaliny, A.I.; McIntyre, L.L.; Shelke, G.V.; Hutchins, E.; Hamamoto, A.; et al. Stem Cell-Derived Exosomes as Nanotherapeutics for Autoimmune and Neurodegenerative Disorders. ACS Nano 2019, 13, 6670-6688. [CrossRef] [PubMed]

26. Yu, L.; Yang, F.; Jiang, L.; Chen, Y.; Wang, K.; Xu, F.; Wei, Y.; Cao, X.; Wang, J.; Cai, Z. Exosomes with membrane-associated TGF-beta1 from gene-modified dendritic cells inhibit murine EAE independently of MHC restriction. Eur. J. Immunol. 2013, 43, 2461-2472. [CrossRef]

27. Casella, G.; Colombo, F.; Finardi, A.; Descamps, H.; Ill-Raga, G.; Spinelli, A.; Podini, P.; Bastoni, M.; Martino, G.; Muzio, L.; et al. Extracellular Vesicles Containing IL-4 Modulate Neuroinflammation in a Mouse Model of Multiple Sclerosis. Mol. Ther. 2018, 26, 2107-2118. [CrossRef]

28. Jiang, Z.Z.; Liu, Y.M.; Niu, X.; Yin, J.Y.; Hu, B.; Guo, S.C.; Fan, Y.; Wang, Y.; Wang, N.S. Exosomes secreted by human urine-derived stem cells could prevent kidney complications from type I diabetes in rats. Stem Cell Res. Ther. 2016, 7, 24. [CrossRef]

29. Kota, D.J.; Wiggins, L.L.; Yoon, N.; Lee, R.H. TSG-6 produced by hMSCs delays the onset of autoimmune diabetes by suppressing Th1 development and enhancing tolerogenicity. Diabetes 2013, 62, 2048-2058. [CrossRef]

30. Shigemoto-Kuroda, T.; Oh, J.Y.; Kim, D.K.; Jeong, H.J.; Park, S.Y.; Lee, H.J.; Park, J.W.; Kim, T.W.; An, S.Y.; Prockop, D.J.; et al. MSC-derived Extracellular Vesicles Attenuate Immune Responses in Two Autoimmune Murine Models: Type 1 Diabetes and Uveoretinitis. Stem Cell Rep. 2017, 8, 1214-1225. [CrossRef] [PubMed]

31. Lanyu, Z.; Feilong, H. Emerging role of extracellular vesicles in lung injury and inflammation. Biomed. Pharmacother. 2019, 113, 108748. [CrossRef] [PubMed]

32. Fujita, Y.; Kadota, T.; Araya, J.; Ochiya, T.; Kuwano, K. Clinical Application of Mesenchymal Stem Cell-Derived Extracellular Vesicle-Based Therapeutics for Inflammatory Lung Diseases. J. Clin. Med. 2018, 7, 355. [CrossRef]

33. Worthington, E.N.; Hagood, J.S. Therapeutic Use of Extracellular Vesicles for Acute and Chronic Lung Disease. Int. J. Mol. Sci. 2020, 21, 2318. [CrossRef] [PubMed]

34. Liu, A.; Zhang, X.; He, H.; Zhou, L.; Naito, Y.; Sugita, S.; Lee, J.W. Therapeutic potential of mesenchymal stem/stromal cell-derived secretome and vesicles for lung injury and disease. Expert Opin. Biol. Ther. 2020, 20, 125-140. [CrossRef] [PubMed]

35. Harrell, C.R.; Jovicic, N.; Djonov, V.; Arsenijevic, N.; Volarevic, V. Mesenchymal Stem Cell-Derived Exosomes and Other Extracellular Vesicles as New Remedies in the Therapy of Inflammatory Diseases. Cells 2019, 8, 1605. [CrossRef]

36. Dabrowska, S.; Andrzejewska, A.; Lukomska, B.; Janowski, M. Neuroinflammation as a target for treatment of stroke using mesenchymal stem cells and extracellular vesicles. J. Neuroinflamm. 2019, 16, 178. [CrossRef] [PubMed]

37. Alvarez-Erviti, L.; Seow, Y.; Yin, H.; Betts, C.; Lakhal, S.; Wood, M.J. Delivery of siRNA to the mouse brain by systemic injection of targeted exosomes. Nat. Biotechnol. 2011, 29, 341-345. [CrossRef]

38. Tang, T.T.; Wang, B.; Lv, L.L.; Liu, B.C. Extracellular vesicle-based Nanotherapeutics: Emerging frontiers in anti-inflammatory therapy. Theranostics 2020, 10, 8111-8129. [CrossRef] [PubMed]

39. Zhuang, X.; Xiang, X.; Grizzle, W.; Sun, D.; Zhang, S.; Axtell, R.C.; Ju, S.; Mu, J.; Zhang, L.; Steinman, L.; et al. Treatment of brain inflammatory diseases by delivering exosome encapsulated anti-inflammatory drugs from the nasal region to the brain. Mol. Ther. 2011, 19, 1769-1779. [CrossRef] [PubMed]

40. Chivero, E.T.; Liao, K.; Niu, F.; Tripathi, A.; Tian, C.; Buch, S.; Hu, G. Engineered Extracellular Vesicles Loaded With miR-124 Attenuate Cocaine-Mediated Activation of Microglia. Front. Cell Dev. Biol. 2020, 8, 573. [CrossRef] [PubMed]

41. Libby, P.; Ridker, P.M.; Maseri, A. Inflammation and atherosclerosis. Circulation 2002, 105, 1135-1143. [CrossRef] [PubMed]

42. Portugal, L.R.; Fernandes, L.R.; Alvarez-Leite, J.I. Host cholesterol and inflammation as common key regulators of toxoplasmosis and artherosclerosis development. Expert Rev. Anti-Infect. Ther. 2009, 7, 807-819. [CrossRef] [PubMed]

43. Frangogiannis, N.G. Regulation of the inflammatory response in cardiac repair. Circ. Res. 2012, 110, 159-173. [CrossRef] [PubMed] 
44. Nahrendorf, M.; Pittet, M.J.; Swirski, F.K. Monocytes: Protagonists of infarct inflammation and repair after myocardial infarction. Circulation 2010, 121, 2437-2445. [CrossRef] [PubMed]

45. Mesri, M.; Altieri, D.C. Endothelial cell activation by leukocyte microparticles. J. Immunol. 1998, 161, 4382-4387. [PubMed]

46. Mesri, M.; Altieri, D.C. Leukocyte microparticles stimulate endothelial cell cytokine release and tissue factor induction in a JNK1 signaling pathway. J. Biol. Chem. 1999, 274, 23111-23118. [CrossRef] [PubMed]

47. Edrissi, H.; Schock, S.C.; Hakim, A.M.; Thompson, C.S. Microparticles generated during chronic cerebral ischemia increase the permeability of microvascular endothelial barriers in vitro. Brain Res. 2016, 1634, 83-93. [CrossRef] [PubMed]

48. Mause, S.F.; von Hundelshausen, P.; Zernecke, A.; Koenen, R.R.; Weber, C. Platelet microparticles: A transcellular delivery system for RANTES promoting monocyte recruitment on endothelium. Arterioscler. Thromb. Vasc. Biol. 2005, 25, 1512-1518. [CrossRef]

49. Rendon, A.; Schakel, K. Psoriasis Pathogenesis and Treatment. Int. J. Mol. Sci. 2019, 20, 1475. [CrossRef]

50. Jacquin-Porretaz, C.; Cordonnier, M.; Nardin, C.; Boullerot, L.; Chanteloup, G.; Vautrot, V.; Adotevi, O.; Garrido, C.; Gobbo, J.; Aubin, F. Increased Levels of Interleukin-17A Exosomes in Psoriasis. Acta Derm. Venereol. 2019, 99, 1143-1147. [CrossRef]

51. Martinez-Sales, V.; Vila, V.; Ricart, J.M.; Vaya, A.; Todoli, J.; Nnnez, C.; Contreras, T.; Ballester, C.; Reganon, E. Increased circulating endothelial cells and microparticles in patients with psoriasis. Clin. Hemorheol. Microcirc. 2015, 60, 283-290. [CrossRef] [PubMed]

52. Pelletier, F.; Garnache-Ottou, F.; Angelot, F.; Biichle, S.; Vidal, C.; Humbert, P.; Saas, P.; Seilles, E.; Aubin, F. Increased levels of circulating endothelial-derived microparticles and small-size platelet-derived microparticles in psoriasis. J. Investig. Dermatol. 2011, 131, 1573-1576. [CrossRef] [PubMed]

53. Pasquali, L.; Svedbom, A.; Srivastava, A.; Rosen, E.; Lindqvist, U.; Stahle, M.; Pivarcsi, A.; Sonkoly, E. Circulating microRNAs in extracellular vesicles as potential biomarkers for psoriatic arthritis in patients with psoriasis. J. Eur. Acad. Dermatol. Venereol. 2020, 34, 1248-1256. [CrossRef]

54. Wang, Z.Y.; Yan, B.X.; Zhou, Y.; Chen, X.Y.; Zhang, J.; Cai, S.Q.; Zheng, M.; Man, X.Y. miRNA Profiling of Extracellular Vesicles Reveals Biomarkers for Psoriasis. J. Investig. Dermatol. 2021, 141, 185-189.e4. [CrossRef] [PubMed]

55. Hong, S.W.; Kim, M.R.; Lee, E.Y.; Kim, J.H.; Kim, Y.S.; Jeon, S.G.; Yang, J.M.; Lee, B.J.; Pyun, B.Y.; Gho, Y.S.; et al. Extracellular vesicles derived from Staphylococcus aureus induce atopic dermatitis-like skin inflammation. Allergy 2011, 66, 351-359. [CrossRef] [PubMed]

56. Kim, J.; Bin, B.H.; Choi, E.J.; Lee, H.G.; Lee, T.R.; Cho, E.G. Staphylococcus aureus-derived extracellular vesicles induce monocyte recruitment by activating human dermal microvascular endothelial cells in vitro. Clin. Exp. Allergy 2019, 49, 68-81. [CrossRef]

57. Kwon, H.I.; Jeong, N.H.; Jun, S.H.; Son, J.H.; Kim, S.; Jeon, H.; Kang, S.C.; Kim, S.H.; Lee, J.C. Thymol attenuates the worsening of atopic dermatitis induced by Staphylococcus aureus membrane vesicles. Int. Immunopharmacol. 2018, 59, 301-309. [CrossRef] [PubMed]

58. Kole, A.K.; Ghosh, A. Cutaneous manifestations of systemic lupus erythematosus in a tertiary referral center. Indian J. Dermatol. 2009, 54, 132-136. [PubMed]

59. Nielsen, C.T.; Ostergaard, O.; Johnsen, C.; Jacobsen, S.; Heegaard, N.H. Distinct features of circulating microparticles and their relationship to clinical manifestations in systemic lupus erythematosus. Arthritis Rheumatol. 2011, 63, 3067-3077. [CrossRef] [PubMed]

60. Ullal, A.J.; Reich, C.F., 3rd; Clowse, M.; Criscione-Schreiber, L.G.; Tochacek, M.; Monestier, M.; Pisetsky, D.S. Microparticles as antigenic targets of antibodies to DNA and nucleosomes in systemic lupus erythematosus. J. Autoimmun. 2011, 36, 173-180. [CrossRef] [PubMed]

61. Mobarrez, F.; Fuzzi, E.; Gunnarsson, I.; Larsson, A.; Eketjall, S.; Pisetsky, D.S.; Svenungsson, E. Microparticles in the blood of patients with SLE: Size, content of mitochondria and role in circulating immune complexes. J. Autoimmun. 2019, 102, 142-149. [CrossRef] [PubMed]

62. Jameson, J.; Ugarte, K.; Chen, N.; Yachi, P.; Fuchs, E.; Boismenu, R.; Havran, W.L. A role for skin gammadelta T cells in wound repair. Science 2002, 296, 747-749. [CrossRef] [PubMed]

63. Martin, P.; Nunan, R. Cellular and molecular mechanisms of repair in acute and chronic wound healing. Br. J. Dermatol. 2015, 173, 370-378. [CrossRef] [PubMed]

64. Plikus, M.V.; Guerrero-Juarez, C.F.; Ito, M.; Li, Y.R.; Dedhia, P.H.; Zheng, Y.; Shao, M.; Gay, D.L.; Ramos, R.; Hsi, T.C.; et al. Regeneration of fat cells from myofibroblasts during wound healing. Science 2017, 355, 748-752. [CrossRef] [PubMed]

65. Sinha, M.; Sen, C.K.; Singh, K.; Das, A.; Ghatak, S.; Rhea, B.; Blackstone, B.; Powell, H.M.; Khanna, S.; Roy, S. Direct conversion of injury-site myeloid cells to fibroblast-like cells of granulation tissue. Nat. Commun. 2018, 9, 936. [CrossRef] [PubMed]

66. Zeng, T.; Wang, X.; Wang, W.; Feng, Q.; Lao, G.; Liang, Y.; Wang, C.; Zhou, J.; Chen, Y.; Liu, J.; et al. Endothelial cell-derived small extracellular vesicles suppress cutaneous wound healing through regulating fibroblasts autophagy. Clin. Sci. 2019, 133, CS20190008. [CrossRef] [PubMed]

67. Wang, X.; Chen, Y.; Zhao, Z.; Meng, Q.; Yu, Y.; Sun, J.; Yang, Z.; Chen, Y.; Li, J.; Ma, T. Engineered exosomes with ischemic myocardium-targeting peptide for targeted therapy in myocardial infarction. J. Am. Heart Assoc. 2018, 7, e008737. [CrossRef] [PubMed]

68. Choi, H.; Kim, Y.; Mirzaaghasi, A.; Heo, J.; Kim, Y.N.; Shin, J.H.; Kim, S.; Kim, N.H.; Cho, E.S.; In Yook, J.; et al. Exosome-based delivery of super-repressor IkappaBalpha relieves sepsis-associated organ damage and mortality. Sci. Adv. 2020, 6, eaaz6980. [CrossRef] 
69. Boilard, E.; Nigrovic, P.A.; Larabee, K.; Watts, G.F.; Coblyn, J.S.; Weinblatt, M.E.; Massarotti, E.M.; Remold-O’'Donnell, E.; Farndale, R.W.; Ware, J.; et al. Platelets amplify inflammation in arthritis via collagen-dependent microparticle production. Science 2010, 327, 580-583. [CrossRef] [PubMed]

70. Ostergaard, O.; Nielsen, C.T.; Iversen, L.V.; Tanassi, J.T.; Knudsen, S.; Jacobsen, S.; Heegaard, N.H. Unique protein signature of circulating microparticles in systemic lupus erythematosus. Arthritis Rheumatol. 2013, 65, 2680-2690. [CrossRef]

71. Cloutier, N.; Tan, S.; Boudreau, L.H.; Cramb, C.; Subbaiah, R.; Lahey, L.; Albert, A.; Shnayder, R.; Gobezie, R.; Nigrovic, P.A.; et al. The exposure of autoantigens by microparticles underlies the formation of potent inflammatory components: The microparticle-associated immune complexes. EMBO Mol. Med. 2013, 5, 235-249. [CrossRef] [PubMed]

72. Lo Cicero, A.; Majkowska, I.; Nagase, H.; Di Liegro, I.; Troeberg, L. Microvesicles shed by oligodendroglioma cells and rheumatoid synovial fibroblasts contain aggrecanase activity. Matrix. Biol. 2012, 31, 229-233. [CrossRef] [PubMed]

73. Li, X.; Zhang, Y.; Yan, Y.; Ciric, B.; Ma, C.G.; Chin, J.; Curtis, M.; Rostami, A.; Zhang, G.X. LINGO-1-Fc-Transduced Neural Stem Cells Are Effective Therapy for Chronic Stage Experimental Autoimmune Encephalomyelitis. Mol. Neurobiol. 2017, 54, 4365-4378. [CrossRef]

74. Zhang, Y.; Han, J.J.; Liang, X.Y.; Zhao, L.; Zhang, F.; Rasouli, J.; Wang, Z.Z.; Zhang, G.X.; Li, X. miR-23b Suppresses Leukocyte Migration and Pathogenesis of Experimental Autoimmune Encephalomyelitis by Targeting CCL7. Mol. Ther. 2018, 26, 582-592. [CrossRef] [PubMed]

75. Selmaj, I.; Mycko, M.P.; Raine, C.S.; Selmaj, K.W. The role of exosomes in CNS inflammation and their involvement in multiple sclerosis. J. Neuroimmunol. 2017, 306, 1-10. [CrossRef] [PubMed]

76. Hawari, F.I.; Rouhani, F.N.; Cui, X.; Yu, Z.X.; Buckley, C.; Kaler, M.; Levine, S.J. Release of full-length 55-kDa TNF receptor 1 in exosome-like vesicles: A mechanism for generation of soluble cytokine receptors. Proc. Natl. Acad. Sci. USA 2004, 101, 1297-1302. [CrossRef] [PubMed]

77. Racanelli, A.C.; Kikkers, S.A.; Choi, A.M.K.; Cloonan, S.M. Autophagy and inflammation in chronic respiratory disease. Autophagy 2018, 14, 221-232. [CrossRef] [PubMed]

78. Germolec, D.R.; Shipkowski, K.A.; Frawley, R.P.; Evans, E. Markers of Inflammation. In Immunotoxicity Testing: Methods and Protocols; DeWitt, J.C., Rockwell, C.E., Bowman, C.C., Eds.; Springer: New York, NY, USA, 2018; pp. 57-79.

79. Raghavendran, K.; Napolitano, L.M. Definition of ALI/ARDS. Crit. Care Clin. 2011, 27, 429-437. [CrossRef] [PubMed]

80. Su, G.; Ma, X.; Wei, H. Multiple Biological Roles of Extracellular Vesicles in Lung Injury and Inflammation Microenvironment. BioMed Res. Int. 2020, 2020, 5608382. [CrossRef] [PubMed]

81. Holtzman, J.; Lee, H. Emerging role of extracellular vesicles in the respiratory system. Exp. Mol. Med. 2020, 52, 887-895. [CrossRef] [PubMed]

82. Alipoor, S.D.; Mortaz, E.; Garssen, J.; Movassaghi, M.; Mirsaeidi, M.; Adcock, I.M. Exosomes and Exosomal miRNA in Respiratory Diseases. Mediat. Inflamm. 2016, 2016, 5628404. [CrossRef] [PubMed]

83. Fujita, Y.; Yoshioka, Y.; Ito, S.; Araya, J.; Kuwano, K.; Ochiya, T. Intercellular communication by extracellular vesicles and their microRNAs in asthma. Clin. Ther. 2014, 36, 873-881. [CrossRef] [PubMed]

84. Chen, J.; Hu, C.; Pan, P. Extracellular Vesicle MicroRNA Transfer in Lung Diseases. Front. Physiol. 2017, 8, 1028. [CrossRef] [PubMed]

85. Lee, H.; Zhang, D.; Laskin, D.L.; Jin, Y. Functional Evidence of Pulmonary Extracellular Vesicles in Infectious and Noninfectious Lung Inflammation. J. Immunol. 2018, 201, 1500-1509. [CrossRef] [PubMed]

86. Levänen, B.; Bhakta, N.R.; Paredes, P.T.; Barbeau, R.; Hiltbrunner, S.; Pollack, J.L.; Sköld, C.M.; Svartengren, M.; Grunewald, J.; Gabrielsson, S.; et al. Altered microRNA profiles in bronchoalveolar lavage fluid exosomes in asthmatic patients. J. Allergy Clin. Immunol. 2013, 131, 894-903.e8. [CrossRef] [PubMed]

87. Sinha, A.; Yadav, A.K.; Chakraborty, S.; Kabra, S.K.; Lodha, R.; Kumar, M.; Kulshreshtha, A.; Sethi, T.; Pandey, R.; Malik, G.; et al. Exosome-enclosed microRNAs in exhaled breath hold potential for biomarker discovery in patients with pulmonary diseases. $J$. Allergy Clin. Immunol. 2013, 132, 219-222.e7. [CrossRef]

88. Sastre, B.; Cañas, J.A.; Rodrigo-Muñoz, J.M.; del Pozo, V. Novel Modulators of Asthma and Allergy: Exosomes and MicroRNAs. Front. Immunol. 2017, 8, 826. [CrossRef]

89. Pattarayan, D.; Thimmulappa, R.K.; Ravikumar, V.; Rajasekaran, S. Diagnostic Potential of Extracellular MicroRNA in Respiratory Diseases. Clin. Rev. Allergy Immunol. 2018, 54, 480-492. [CrossRef]

90. McVey, M.J.; Maishan, M.; Blokland, K.E.C.; Bartlett, N.; Kuebler, W.M. Extracellular vesicles in lung health, disease, and therapy. Am. J. Physiol. Lung Cell Mol. Physiol. 2019, 316, L977-L989. [CrossRef]

91. Harrell, C.R.; Sadikot, R.; Pascual, J.; Fellabaum, C.; Jankovic, M.G.; Jovicic, N.; Djonov, V.; Arsenijevic, N.; Volarevic, V. Mesenchymal Stem Cell-Based Therapy of Inflammatory Lung Diseases: Current Understanding and Future Perspectives. Stem Cells Int. 2019, 2019, 4236973. [CrossRef]

92. Gowen, A.; Shahjin, F.; Chand, S.; Odegaard, K.E.; Yelamanchili, S.V. Mesenchymal Stem Cell-Derived Extracellular Vesicles: Challenges in Clinical Applications. Front. Cell Dev. Biol. 2020, 8, 149. [CrossRef] [PubMed]

93. Baek, G.; Choi, H.; Kim, Y.; Lee, H.C.; Choi, C. Mesenchymal Stem Cell-Derived Extracellular Vesicles as Therapeutics and as a Drug Delivery Platform. Stem Cells Transl. Med. 2019, 8, 880-886. [CrossRef] [PubMed]

94. Vandendriessche, C.; Bruggeman, A.; Van Cauwenberghe, C.; Vandenbroucke, R.E. Extracellular Vesicles in Alzheimer's and Parkinson's Disease: Small Entities with Large Consequences. Cells 2020, 9, 2485. [CrossRef] [PubMed] 
95. Trotta, T.; Panaro, M.A.; Cianciulli, A.; Mori, G.; Di Benedetto, A.; Porro, C. Microglia-derived extracellular vesicles in Alzheimer's Disease: A double-edged sword. Biochem. Pharmacol. 2018, 148, 184-192. [CrossRef] [PubMed]

96. Groot, M.; Lee, H. Sorting Mechanisms for MicroRNAs into Extracellular Vesicles and Their Associated Diseases. Cells 2020, 9 , 1044. [CrossRef] [PubMed]

97. Delpech, J.C.; Herron, S.; Botros, M.B.; Ikezu, T. Neuroimmune Crosstalk through Extracellular Vesicles in Health and Disease. Trends Neurosci. 2019, 42, 361-372. [CrossRef] [PubMed]

98. Sproviero, D.; La Salvia, S.; Giannini, M.; Crippa, V.; Gagliardi, S.; Bernuzzi, S.; Diamanti, L.; Ceroni, M.; Pansarasa, O.; Poletti, A.; et al. Pathological Proteins Are Transported by Extracellular Vesicles of Sporadic Amyotrophic Lateral Sclerosis Patients. Front. Neurosci. 2018, 12, 487. [CrossRef]

99. Leng, F.; Edison, P. Neuroinflammation and microglial activation in Alzheimer disease: Where do we go from here? Nat. Rev. Neurol. 2020, 17, 1-16.

100. Li, T.R.; Wang, X.N.; Sheng, C.; Li, Y.X.; Li, F.Z.; Sun, Y.; Han, Y. Extracellular vesicles as an emerging tool for the early detection of Alzheimer's disease. Mech. Ageing Dev. 2019, 184, 111175. [CrossRef]

101. Shaimardanova, A.A.; Solovyeva, V.V.; Chulpanova, D.S.; James, V.; Kitaeva, K.V.; Rizvanov, A.A. Extracellular vesicles in the diagnosis and treatment of central nervous system diseases. Neural Regen. Res. 2020, 15, 586-596.

102. Amor, S.; Puentes, F.; Baker, D.; van der Valk, P. Inflammation in neurodegenerative diseases. Immunology 2010, 129, 154-169. [CrossRef] [PubMed]

103. Ransohoff, R.M. How neuroinflammation contributes to neurodegeneration. Science 2016, 353, 777-783. [CrossRef] [PubMed]

104. Schain, M.; Kreisl, W.C. Neuroinflammation in Neurodegenerative Disorders-A Review. Curr. Neurol. Neurosci. Rep. $2017,17,25$. [CrossRef] [PubMed]

105. Gupta, A.; Pulliam, L. Exosomes as mediators of neuroinflammation. J. Neuroinflamm. 2014, 11, 68. [CrossRef] [PubMed]

106. Elia, C.A.; Losurdo, M.; Malosio, M.L.; Coco, S. Extracellular Vesicles from Mesenchymal Stem Cells Exert Pleiotropic Effects on Amyloid-beta, Inflammation, and Regeneration: A Spark of Hope for Alzheimer's Disease from Tiny Structures? Bioessays 2019, 41, e1800199. [CrossRef] [PubMed]

107. Drommelschmidt, K.; Serdar, M.; Bendix, I.; Herz, J.; Bertling, F.; Prager, S.; Keller, M.; Ludwig, A.K.; Duhan, V.; Radtke, S.; et al. Mesenchymal stem cell-derived extracellular vesicles ameliorate inflammation-induced preterm brain injury. Brain Behav. Immun. 2017, 60, 220-232. [CrossRef] [PubMed]

108. Luan, X.; Sansanaphongpricha, K.; Myers, I.; Chen, H.; Yuan, H.; Sun, D. Engineering exosomes as refined biological nanoplatforms for drug delivery. Acta Pharmacol. Sin. 2017, 38, 754-763. [CrossRef] [PubMed]

109. Piffoux, M.; Nicolás-Boluda, A.; Mulens-Arias, V.; Richard, S.; Rahmi, G.; Gazeau, F.; Wilhelm, C.; Silva, A.K. Extracellular vesicles for personalized medicine: The input of physically triggered production, loading and theranostic properties. Adv. Drug Deliv. Rev. 2019, 138, 247-258. [CrossRef]

110. Gudbergsson, J.M.; Jønsson, K.; Simonsen, J.B.; Johnsen, K.B. Systematic review of targeted extracellular vesicles for drug delivery-considerations on methodological and biological heterogeneity. J. Control. Release 2019, 306, 108-120. [CrossRef]

111. Delcayre, A.; Estelles, A.; Sperinde, J.; Roulon, T.; Paz, P.; Aguilar, B.; Villanueva, J.; Khine, S.; Le Pecq, J.-B. Exosome display technology: Applications to the development of new diagnostics and therapeutics. Blood Cells Mol. Dis. 2005, 35, 158-168. [CrossRef]

112. Hartman, Z.C.; Wei, J.; Glass, O.K.; Guo, H.; Lei, G.; Yang, X.-Y.; Osada, T.; Hobeika, A.; Delcayre, A.; Le Pecq, J.-B. Increasing vaccine potency through exosome antigen targeting. Vaccine 2011, 29, 9361-9367. [CrossRef] [PubMed]

113. Simhadri, V.R.; Reiners, K.S.; Hansen, H.P.; Topolar, D.; Simhadri, V.L.; Nohroudi, K.; Kufer, T.A.; Engert, A.; Pogge von Strandmann, E. Dendritic cells release HLA-B-associated transcript-3 positive exosomes to regulate natural killer function. PLoS ONE 2008, 3, e3377. [CrossRef] [PubMed]

114. Tian, Y.; Li, S.; Song, J.; Ji, T.; Zhu, M.; Anderson, G.J.; Wei, J.; Nie, G. A doxorubicin delivery platform using engineered natural membrane vesicle exosomes for targeted tumor therapy. Biomaterials 2014, 35, 2383-2390. [CrossRef] [PubMed]

115. Yim, N.; Ryu, S.W.; Choi, K.; Lee, K.R.; Lee, S.; Choi, H.; Kim, J.; Shaker, M.R.; Sun, W.; Park, J.H.; et al. Exosome engineering for efficient intracellular delivery of soluble proteins using optically reversible protein-protein interaction module. Nat. Commun. 2016, 7, 12277. [CrossRef] [PubMed]

116. Shalitin, D.; Yang, H.; Mockler, T.C.; Maymon, M.; Guo, H.; Whitelam, G.C.; Lin, C. Regulation of Arabidopsis cryptochrome 2 by blue-light-dependent phosphorylation. Nature 2002, 417, 763-767. [CrossRef]

117. Kooijmans, S.; Fliervoet, L.; Van Der Meel, R.; Fens, M.; Heijnen, H.; en Henegouwen, P.V.B.; Vader, P.; Schiffelers, R. PEGylated and targeted extracellular vesicles display enhanced cell specificity and circulation time. J. Control. Release 2016, 224, 77-85. [CrossRef] [PubMed]

118. Riches, A.; Campbell, E.; Borger, E.; Powis, S. Regulation of exosome release from mammary epithelial and breast cancer cells-a new regulatory pathway. Eur. J. Cancer 2014, 50, 1025-1034. [CrossRef] [PubMed]

119. Franzen, C.A.; Simms, P.E.; Van Huis, A.F.; Foreman, K.E.; Kuo, P.C.; Gupta, G.N. Characterization of uptake and internalization of exosomes by bladder cancer cells. BioMed Res. Int. 2014, 2014, 619829. [CrossRef]

120. Smyth, T.; Kullberg, M.; Malik, N.; Smith-Jones, P.; Graner, M.W.; Anchordoquy, T.J. Biodistribution and delivery efficiency of unmodified tumor-derived exosomes. J. Control. Release 2015, 199, 145-155. [CrossRef] 
121. Smyth, T.; Petrova, K.; Payton, N.M.; Persaud, I.; Redzic, J.S.; Graner, M.W.; Smith-Jones, P.; Anchordoquy, T.J. Surface functionalization of exosomes using click chemistry. Bioconjug. Chem. 2014, 25, 1777-1784. [CrossRef]

122. Presolski, S.I.; Hong, V.P.; Finn, M. Copper-catalyzed azide-alkyne click chemistry for bioconjugation. Curr. Protoc. Chem. Biol. 2011, 3, 153-162. [CrossRef] [PubMed]

123. Tian, T.; Zhang, H.-X.; He, C.-P.; Fan, S.; Zhu, Y.-L.; Qi, C.; Huang, N.-P.; Xiao, Z.-D.; Lu, Z.-H.; Tannous, B.A. Surface functionalized exosomes as targeted drug delivery vehicles for cerebral ischemia therapy. Biomaterials 2018, 150, 137-149. [CrossRef] [PubMed]

124. Oh, M.; Lee, J.; Kim, Y.J.; Rhee, W.J.; Park, J.H. Exosomes Derived from Human Induced Pluripotent Stem Cells Ameliorate the Aging of Skin Fibroblasts. Int. J. Mol. Sci. 2018, 19, 1715. [CrossRef] [PubMed]

125. Zhang, N.; Chittasupho, C.; Duangrat, C.; Siahaan, T.J.; Berkland, C. PLGA nanoparticle- peptide conjugate effectively targets intercellular cell-adhesion molecule-1. Bioconjug. Chem. 2008, 19, 145-152. [CrossRef] [PubMed]

126. Nahrendorf, M.; Jaffer, F.A.; Kelly, K.A.; Sosnovik, D.E.; Aikawa, E.; Libby, P.; Weissleder, R. Noninvasive vascular cell adhesion molecule-1 imaging identifies inflammatory activation of cells in atherosclerosis. Circulation 2006, 114, 1504-1511. [CrossRef] [PubMed]

127. Pi, F.; Binzel, D.W.; Lee, T.J.; Li, Z.; Sun, M.; Rychahou, P.; Li, H.; Haque, F.; Wang, S.; Croce, C.M. Nanoparticle orientation to control RNA loading and ligand display on extracellular vesicles for cancer regression. Nat. Nanotechnol. 2018, 13, 82-89. [CrossRef] [PubMed]

128. Salazar, M.D.A.; Ratnam, M. The folate receptor: What does it promise in tissue-targeted therapeutics? Cancer Metastasis Rev. 2007, 26, 141-152. [CrossRef]

129. Zhao, Z.; Ukidve, A.; Kim, J.; Mitragotri, S. Targeting strategies for tissue-specific drug delivery. Cell 2020, 181, 151-167. [CrossRef]

130. Tran, P.H.; Xiang, D.; Nguyen, T.N.; Tran, T.T.; Chen, Q.; Yin, W.; Zhang, Y.; Kong, L.; Duan, A.; Chen, K. Aptamer-guided extracellular vesicle theranostics in oncology. Theranostics 2020, 10, 3849. [CrossRef]

131. Gobbo, J.; Marcion, G.; Cordonnier, M.; Dias, A.M.; Pernet, N.; Hammann, A.; Richaud, S.; Mjahed, H.; Isambert, N.; Clausse, V. Restoring anticancer immune response by targeting tumor-derived exosomes with a HSP70 peptide aptamer. J. Natl. Cancer Inst. 2016, 108, djv330. [CrossRef]

132. Li, C.; Guo, F.; Wang, X.; Liu, D.; Wu, B.; Wang, F.; Chen, W. Exosome-based targeted RNA delivery for immune tolerance induction in skin transplantation. J. Biomed. Mater. Res. Part A 2020, 108, 1493-1500. [CrossRef] [PubMed]

133. Cheng, Q.; Shi, X.; Han, M.; Smbatyan, G.; Lenz, H.-J.; Zhang, Y. Reprogramming exosomes as nanoscale controllers of cellular immunity. J. Am. Chem. Soc. 2018, 140, 16413-16417. [CrossRef] [PubMed] 